\title{
Peranan Microscope Smartphone sebagai media pembelajaran Fisika berbasis STEM untuk meningkatkan pemahaman konsep Optik
}

\author{
Maria Dewati ${ }^{1}$, Yoga Budi Bhakti ${ }^{2}$, Irnin Agustina Dwi Astuti ${ }^{3}$ \\ 1,2,3 Program Studi Pendidikan Fisika, Universitas Indraprasta PGRI Jakarta, \\ Jln. Raya Tengah, Jakarta Timur 13760, Indonesia \\ Email: merrdewati@gmail.com
}

\begin{abstract}
STEM-based learning can help students to use technology and compile an experiment that can prove a postulate or concept. The purpose of this study was to determine the role of Smartphone Microscopes as STEM-based physics learning media to improve understanding of optical concepts. The method used in this study is a quasi-experimental method with a Post-Test Only Control Group Design research design, which involved 84 Physic Education students as research samples. Determination of the sample using a cluster Random sampling technique. The research instrument used was an observation sheet and an optical concept understanding test sheet. The data analysis technique used is .the Paired Sample T-test. The results showed that 1) smartphone microscope is one of the most effective learning media in STEM learning, and 2) The understanding of student intelligence concepts increases through STEM learning
\end{abstract}

Keywords: Microscopes Smartphone, STEM, concept understanding

\begin{abstract}
Abstrak: Pembelajaran berbasis STEM dapat membantu peserta didik untuk menggunakan teknologi dan merangkai sebuah percobaan yang dapat membuktikan sebuah hukum atau konsep sains. Tujuan penelitian ini untuk mengetahui peranan Microscope Smartphone sebagai media pembelajaran Fisika dalam implementasi pembelajaran berbasis STEM untuk meningkatkan pemahaman konsep optik. Metode yang digunakan dalam penelitian ini adalah metode kuasi-eksperimen dengan desain penelitian The Pretest Posttest Only Control Group Design, yang melibatkan 84 mahasiswa Pendidikan Fisika sebagai sampel penelitian. Penentuan sampel menggunakan teknik cluster rundom sampling. Instrumen penelitian yang digunakan adalah lembar observasi dan lembar tes pemahaman konsep optik. Teknik analisis data yang digunakan Paired Sample T-test. Hasil penelitian menunjukkan bahwa 1) microscope smartphone merupakan salah satu media pembelajaran yang cukup efektif dalam pembelajaran STEM, dan 2) Pemahaman konsep optik mahasiswa meningkatkan melalui pembelajaran STEM
\end{abstract}

Kata kunci: Microscopes Smartphone, STEM, pemahaman konsep

\section{PENDAHULUAN}

Pendidikan merupakan salah satu aspek yang sangat penting dalam kehidupan manusia. Sebuah negara dikatakan maju atau tidaknya dapat dilihat dari pendidikan yang diterapkan di negara tersebut. Persaingan yang semakin ketat di era globalisasi ini mengharuskan sumber daya manusia memiliki kualitas yang baik dan profesional di berbagai bidang kehidupan. Para siswa yang hidup di era ini haruslah memiliki keterampilan abad 21 agar dapat bersaing, bukan hanya dengan rekan sebangsanya, tetapi juga rekan seusianya dari negara lain.

Keterampilan abad 21 ini meliputi keterampilan dalam literasi era digital, berpikir inventif, komunikasi yang efektif, dan produktivitas yang tinggi (Lemke, 2003). Berdasarkan hasil pemetaan TIMSS dan PISA dalam bidang literasi sains. Indonesia menduduki peringkat ke 40 dari 42 negara dalam pemetaan TIMSS 2011 dan menduduki peringkat ke 64 dari 65 negara dalam pemetaan PISA 2012. Hal ini menggambarkan bahwa praktek pendidikan di Indonesia masih belum optimal (Dikdasmen, 2014). Salah satu kendala dalam kurangnya kemampuan 
siswa Indonesia dalam mencapai kompetensi adalah strategi pembelajaran yang digunakan. Pembelajaran yang dilakukan di sekolah-sekolah formal saat ini masih banyak yang menggunakan strategi pembelajaran yang bersifat konvensional, seperti ceramah.

Dengan adanya kasus seperti ini, maka strategi pembelajaran yang dilakukan di dalam kelas harus mengalami perubahan. Khusus untuk bidang sains, salah satu pendekatan pembelajaran yang cocok diterapkan adalah pendekatan STEM (Science Technology Engineering Mathematics). Hal ini karena dalam pembelajaran dengan pendekatan STEM siswa tidak hanya diajarkan secara teori saja, tetapi juga praktik dalam bentuk proyek, sehingga siswa mengalami langsung proses pembelajaran, dan ini sesuai dengan hakikat IPA (Rustaman et al., 2003).

Pada pembelajaran STEM, siswa belajar melalui pembelajaran berbasis proyek (Fan \& Ritz). Namun, dalam pembelajaran STEM ini implementasi pembelajaran berbasis proyek berbeda dengan yang sudah biasa dilakukan. Pada STEM terdapat proses pikir, desain, buat, dan uji. Dimana setelah siswa selesai membuat proyek, proyek tersebut akan diuji apakah sudah sesuai dengan yang diharapkan atau tidak. Jika tidak, maka akan dilakukan pendesainan ulang. Proses ini dilakukan karena pembelajaran STEM lebih menekankan pada tahap engineering atau rekayasa, namun tetap beririsan dengan proses ilmiah (sciencetific process). Tahap rekayasa yang dimaksud adalah merancang suatu objek, proses, ataupun sistem yang disesuaikan dengan kebutuhan atau keinginan manusia.

Di Indonesia, pembelajaran STEM belum populer jika dibandingkan di negara maju, seperti Amerika Serikat. Namun, pembelajaran STEM ini mulai dilirik pemerintah untuk dimasukkan ke dalam kurikulum sekolah (Republika, 2015). STEM di Indonesia masih dalam tahap berkembang, dan saat ini belum terdapat penilaian baku yang dapat diterapkan khusus untuk pembelajaran STEM, termasuk di Indonesia. STEM merupakan displin ilmu yang berkaitan erat satu sama lain.Sains memerlukan matematika sebagai alat dalam mengolah data, sedangkan teknologi dan teknikmerupakan aplikasi dari sains.

Pendekatan STEM dalam pembelajaran diharapkan dapat menghasilkan pembelajaran yang bermakna bagi siswa melalui integrasi pengetahuan, konsep, dan keterampilan secara sistematis. Beberapa manfaat dari pendekatan STEM membuat siswa mampu memecahkan masalah menjadi lebih baik, inovator, inventors, mandiri, pemikir logis, dan literasi teknologi (Morrison dalam Stohlmann, Moore, \& Roehrig, 2012). Melalui pembelajaran STEM, siswa memiliki literasi sains dan teknologi yang nampak dari membaca, menulis, mengamati, serta melakukan sains sehingga dapat dijadikan bekal untuk hidup bermasyarakat dan memecahkan permasalahan yang dihadapi dalam kehidupan sehari-hari yang terkait dengan bidang ilmu STEM (Mayasari et al., 2014). Praktek sains dan teknik dalam pendekatan STEM dibagi menjadi 8 komponen yang dapat dipilih dalam pemecahan permasalahan dalam pembelajaran (Evans, 2012). Kedelapan komponen tersebut terdiri dari membuat pertanyaan dan mendefinisikan masalah, mengembangkan dan menggunakan model, merencanakan dan melakukan investigasi, menganalisis dan mengintepretasikan data, menggunakan pemikiran matematika dan komputasi, mengkonstruksi penjelasan dan merancang solusi, pelibatan dalam argumentasi dan pembuktian, serta mengumpulkan, mengevaluasi, dan mengkomunikasikan informasi. Pemilihan komponen yang akan digunakan dalam pembelajaran bergantung pada keterampilan yang ingin dikembangkan pada peserta didik serta masalah yang ingin dipecahkan.

Berdasarkan observasi pada mata kuliah Fisika Optik di Universitas Swasta di jakarta, diperoleh informasi bahwa mahasiswa hanya belajar konsep optik dari ranah kognitif saja. Keterampilan mahasiswa dalam merangkai alat kurang, terutama dalam alat optik. Pemahaman konsep optik tergolong rendah, dilihat dari nilai tugas rata-rata mahasiswa hanya 
bisa memahami persamaan rumus matematis fisika optik tetapi mereka tidak paham konsep dasar optik. Oleh karena itu perlu adanya media pembelajaran yang mampu mengubah paradigma dan pemahaman konsep mahasiswa.

Microscope smartphone salah satu alternatif media pembelajaran dalam konsep optik yang mampu mengubah psikomotorik mahasiswa dalam memahami konsep optik. Dengan microscope smarthphone dapat diintegrasikan dengan pembelajaran STEM.

\section{METODE PENELITIAN}

Metode yang digunakan dalam penelitian ini adalah metode kuasi-eksperimen dengan desain penelitian The Pretest Posttest Only Control Group Design, yang melibatkan 84 mahasiswa Pendidikan Fisika sebagai sampel penelitian. Penentuan sampel menggunakan teknik cluster rundom sampling. Instrumen penelitian yang digunakan adalah lembar observasi dan lembar tes pemahaman konsep optik. Tes pemahaman konsep optik merupakan tes tertulis dengan tipe pilihan ganda. Sebelum diterapkan tes evaluasi terlebih dahulu diuji coba untuk dianalisis validitas, reliabilitas, daya pembeda, dan tingkat kesukaran soal.

Efektivitas penggunaan media microscope smartphone dalam pemebelajaran Fisika ditinjau berdasarkan perbandingan rata-rata gain yang dinormalisasi antara yang dicapai oleh pretest dan postest. Suatu pembelajaran dikatakan lebih efektif dari pembelajaran lainnya jika menghasilkan rata-rata nilai gain yang dinormalisasi lebih besar (Oligiv, 2000). Untuk perhitungan gain yang dinormalisasi, g, dan pengklasifikasiannya digunakan persamaan yang dirumuskan oleh Hake (1998) seperti berikut:

$$
g=\frac{S_{\text {post }}-S_{\text {pre }}}{S_{M I}-S_{\text {pre }}}
$$

$\mathrm{S}_{\text {post }}, \mathrm{S}_{\text {pre }}$ dan $\mathrm{S}_{\mathrm{MI}}$ adalah skor tes akhir, skor tes awal dan skor maksimum ideal; Sedangkan untuk mengidentifikasi terjadinya miskonsepsi digunakan metode CRI (Certainty of Response Index) yang dikembangkan oleh Hasan, dkk.(1999).

Tabel 1. Indikator nilai Gain Standar

\begin{tabular}{cc}
\hline Interval & Kategori \\
\hline $\mathrm{g}>0,7$ & Tinggi \\
$0,3<\mathrm{g} \leq 0,7$ & Sedang \\
$\mathrm{g} \leq 0,3$ & Rendah \\
\hline
\end{tabular}

Selain menggunakan analisis penguatan standar, analisis perbedaan sebelum dan sesudah tindakan juga dapat menggunakan analisis T-test berpasangan atau Paired Sample T-test digunakan untuk membandingkan rerata dari dua set data (sebelum dan sesudah implementasi pembelajaran STEM dengan microscope smartphone) secara berpasangan. Pengujian hipotesis yang digunakan dalam studi ini adalah tes partai yang tepat. Dalam tes pihak ini, ketentuan berlaku bahwa, jika harga $t_{\text {hitung }}$ lebih besar dari atau sama dengan $(>) t_{\text {tabel }}$, maka $\mathrm{H}_{0}$ diterima dan $\mathrm{H}_{0}$ ditolak.

Dalam studi ini, dua set data adalah pemahaman konsep optik mahasiswa sebelum dan sesudah perlakuan, pada tingkat kepercayaan 95\% $(\alpha=0,05)$. Sebelum melakukan analisis data dengan uji T-test berpasangan, pertama-tama diuji apakah kedua data tersebut didistribusikan secara normal atau tidak. Statistik tes yang digunakan adalah tes normalitas Lilliefors (Kolmogorov-Smirnov) menggunakan SPSS 16. 


\section{HASIL DAN PEMBAHASAN}

Pembelajaran fisika berbasis STEM dengan menggunakan media microscope smartphone dalam pembelajaran optik, serta mengintegrasikan konsep matematika dalam menghitung nilai perbesaran bayangan. Hal tersebut dilakukan untuk meningkatkan motivasi, kreasi serta inovasi siswa dalam menciptakan suatu teknologi. Berdasarkan hasil wawancara respon mahasiswa, semua mahasiswa (100\%) merasa senang mengikuti pembelajaran tersebut, sebagian besar $(80 \%)$ merasa mereka dirangsang berpikir secara aktif dalam menyelesaikan masalah, meskipun hanya 60\% mahasiswa yang memahami semua bagian pembelajaran (pemahaman konsep optik), dapat dilihat pada gambar 1.

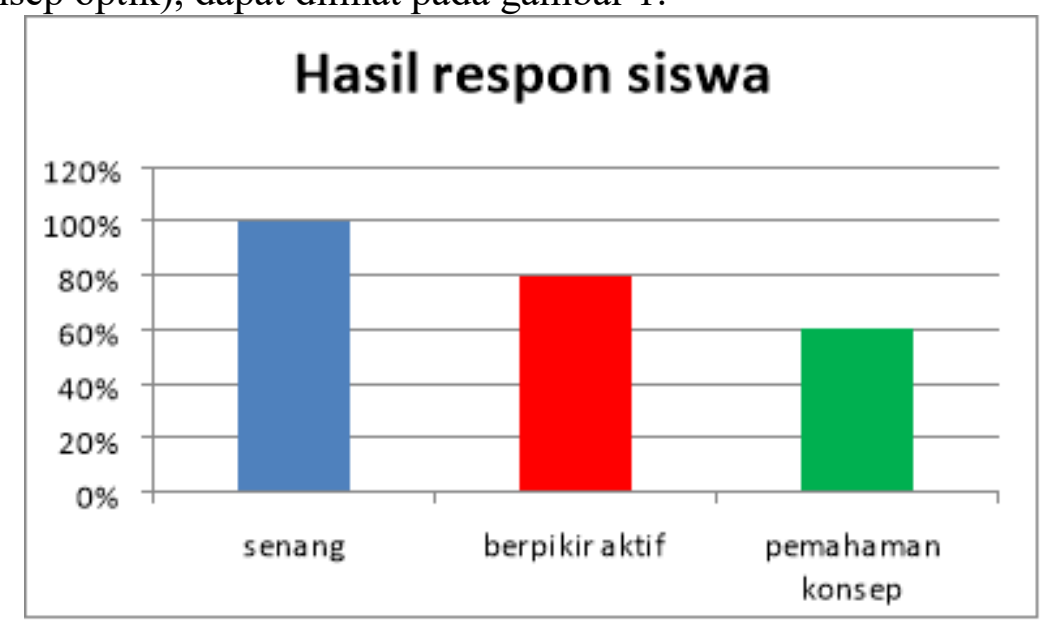

Gambar 1. Hasil respon siswa terhadaap pembelajaran STEM dengan microscope smartphone

Pemahaman konsep siswa dapat dilihat dari hasil tes yang dilakukan setelah pembelajaran STEM dengan bantuan media microscope smartphone diterapkan. Sebelum tes digunakan sebelumnya diuji coba terlebih dahulu untuk melihat validitas, reliabiitas, daya pembeda, dan tingkat kesukaran sol. Terdapat 25 soal pilihan ganda yang valid yang selanjutnya digunakan untuk tes evaluasi. Nilai yang diperoleh selanjutnya dianalisis untuk melihat pengaruh pembelajaran STEM dengan microscope smartphone terhadap pemahaman konsep optik mahasiswa. Rekapitulasi nilai pemahaman konsep optik mahasiswa ditunjukkan pada Tabel 1.

Tabel 2. Deskripsi nilai pemahaman konsep optik

\begin{tabular}{lcc}
\hline Deskripsi & $\begin{array}{c}\text { Sebelum } \\
\text { pembelajaran } \\
\text { STEM }\end{array}$ & $\begin{array}{c}\text { Setelah } \\
\text { pembelajaran } \\
\text { STEM }\end{array}$ \\
\hline Nilai maksimum & 64 & 86 \\
Nilai minimum & 48 & 67 \\
Nilai rata-rata & 58 & 76 \\
\hline
\end{tabular}

Pemahaman konsep optik sebelum dan setelah pembelajaran STEM dengan microscope smartphone cukup berbeda. Rata-rata tes awal adalah 48 dan tes ahir setelah pembelajaran sebesar 76. Setelah pembelajaran flipped clas STEM dengan microscope smartphone, pemahaman konsep optik mahasiswa terjadi peningkatan sebesar 23,68 \%. Untuk melihat peningkatan pemahaman konsep optik mahasiswa dilihat dari analisis nilai rata-rata pretest dan postest berdasarkan rumus Gain Standar. Dengan rumus Gain Standar diperoleh nilainya sebesar 0,82 dengan kategori "tinggi". 
Sebelum melakukan analisis data dengan uji-t berpasangan, terlebih dahulu kita uji apakah kedua data menyebar normal atau tidak. Statistik uji yang digunakan adalah Lilliefors (Kolmogorov-Smirnov) normality test. Nilai ( $p$-value) uji normalitas untuk data sebelum dan sesudah penerapan STEM dengan microscope smartphone lebih besar dari 0.05, maka kesimpulan statistika yang diambil adalah menerima $H_{0}$, artinya dapat dikatakan bahwa kedua data berasal dari populasi yang menyebar normal. Dengan kata lain, data berdistribusi normal (dengan $p$-value $=0.790)$. Oleh karena itu, uji-t berpasangan dapat diterapkan.

Setelah dianalisis dengan menggunakan SPSS diperoleh $P$-value dari uji-t berpasangan adalah 0.000, yaitu lebih kecil dari 0.05. Dengan demikian, kesimpulan statistika adalah menolak $H_{0}$. Hal ini berarti bahwa nilai pemahaman konsep optik mahasiswa sebelum dan setelah diberi tindakan tidak sama dengan nol. Selisih kedua rata-rata antara pretest dan postest adalah 18. Dengan demikian, dapat disimpulkan bahwa penerapan STEM dengan microscope smartphone efektif digunakan dalam pembelajaran fisika, dengan tingkat kepercayaan sebesar $95 \%$.

Secara keseluruhan, pembelajaran berbasis STEM ini mampu meningkatkan motivasi siswa dan kreasi siswa dalam belajar fisika (Afriana dkk, 2016). Meskipun mereka belum memahami istilah STEM, namun mereka merasakan pembelajaran dengan metode ini mampu membuat mereka bergerak dan berpikir secara aktif. Pendekatan STEM merupakan pendekatan yang saling mengaitkan dan mengintegrasikan subjek STEM guna menciptakan pembelajaran yang berbasis permasalahan kehidupan sehari-hari sehingga dapat melatih peserta didik dalam menerapkan ilmu yang dipelajari di sekolah dengan fenomena yang terjadi dalam dunia nyata (Anggraini \& Huzaifah, 2017) .

Pembelajaran dengan STEM dapat mengaktifkan mahasiswa ketika pembelajaran di kelas, sehingga pembelajaran berpusat pada mahasiswa (student center). Sejalan dengan prinsip Konstruktivisme belajar teori yang memusatkan proses pembelajaran yang dialami langsung membentuk konsep pembelajaran dan pemahaman (Sulaeman, Indrawati, \& Noeraida, 2017). Menurt Sulistyowati dkk (2017), pendidikan STEM dikembangkan untuk menghasilkan pembelajaran yang bermakna melalui integrasi pengetahuan, konsep, dan keterampilan yang sistematis.

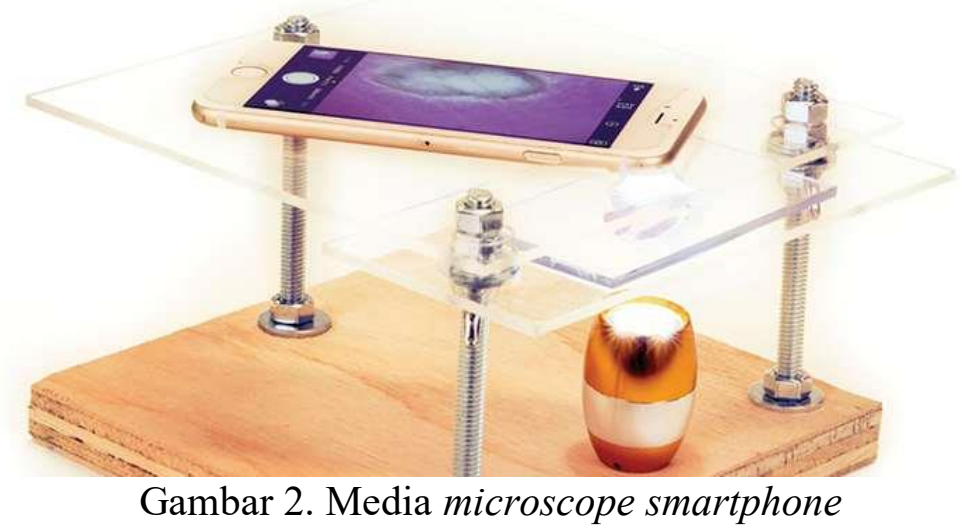

Dengan adanya peranan micrsocope smartphone dapat meningkatkan kemampuan psikomotorik atau skill mahasiswa dalam merangkai alat untuk membantu pemahaman mereka dalam materi optik. Media microscope smartphone sangat cocok dalam pembelajaran STEM. Science dari konsep fisikanya yaitu materi optik, technology dilihat dari merangkai alat micrsocope smartphone, engineering dilihat dari mendesain dan merangkat micrsocope smartphone, dan mathematic dilihat dari manganalisis persamaan mikroskop dalam 
mengitung perbesaran bayangan. Pengintegrasian beberapa disiplin ilmu ini dalam satu kesatuan diharapkan mampu menghasilkan lulusan yang kompeten dan berkualitas tidak saja dalam hal penguasaan konsep tetapi juga dalam mengaplikasikannya pada kehidupan. Pendekatan STEM merupakan perpaduan dari sains, teknologi, enjiniring, dan matematika ke dalam satu kurikulum secara keseluruhan (Jones, 2008).

Pendidikan STEM dibentuk berdasarkan perpaduan beberapa disiplin ilmu menjadi satu bentuk kesatuan pendekatan baru yang utuh. Disiplin ilmu yang menjadi komponen dari pendekatan STEM yaitu sains, teknologi, enjinering, dan matematika (Ismail dkk, 2016). Program pendidikan STEM dinilai perlu mengintegrasikan keterampilan yang harus dimiliki siswa berdasarkan standar NRC (2010). Keterampilan tersebut adalah 1) Adaptability (keterampilan untuk beradaptasi terhadap suatu kondisi yang tidak umum), 2) Complex communication skills (keterampilan dalam memproses dan menginterpretasi informasi baik secara verbal maupun nonverbal), 3) Non-routine problem solving (kemamuan untuk menyelesaikan masalah yang tidak umum), 4) Self management and self development (kemampuan untuk bekerja secara otomatis dengan kelompok maupun sendiri), 5) System thinking (kemampuan untuk memahami kerja seluruh sistem serta memahami bagaimana pengaruh suatu tindakan perubahan terhadap sistem tersebut).

\section{SIMPULAN}

Berdasarkan hasil penelitian menunjukkan bahwa 1) microscope smartphone merupakan salah satu media pembelajaran yang cukup efektif dalam pembelajaran STEM, dan 2) Pemahaman konsep optik mahasiswa meningkat melalui pembelajaran STEM. Terlihat dengan nilai rata-rata pemahaman konsep optik sebelum (pretest) dan setelah pembelajaran (postest) mengalami peningkatan sebesar 23,68\%. Pembelajaran STEM mampu mengubah keterampilan mahasiswa dan mengaktifkan mahasiswa dalam pembelajaran sehingga pembelajaran terlihat lebih menyenangkan.

Pada faktanya, pada pembelajaran STEM mahasiswa belum terbiasa sehingga terlihat bingung di awal pembelajaran ketika diberikan lembar kerja. Membuthkan waktu yang digunakan dalam pembelajaran STEM. Oleh karena itu, pengaturan waktu pembelajaran yang lebih baik sangat diperlukan pada implementasi selanjutnya.

\section{DAFTAR PUSTAKA}

Afriana, J., Permanasari, A., \& Fitriani, A. (2016). Penerapan project based learning terintegrasi STEM untuk meningkatkan literasi sains siswa ditinjau dari gender. Jurnal Inovasi Pendidikan IPA, 2(2), 202-212.

Anggraini, F. I., \& Huzaifah, S. (2017, October). Implementasi STEM dalam pembelajaran IPA di Sekolah Menengah Pertama. In Seminar Nasional Pendidikan IPA (Vol. 1, No. 1, pp. 722-731).

Evans, L. (2012). GCSE results 2012: exam breakdown by subject, gender and area. Retrieved September 4, 2019, from https://www.theguardian.com/news/datablog/2012/aug/23/gcse-results-2012-exambreakdown

Fan, S.C.C., \& Ritz, J.M. (2019). International Views of STEM Education. Tersedia http://www.iteea.org/Conference/PATT/PATT28/Fan\%20Ritz.pdf $\quad$ Diakses: 9 September 2019 (18:43)

Hake, R. R. (1998). Interactive-engagement versus traditional methods: A six-thousandstudent survey of mechanics test data for introductory physics courses. American journal of Physics, 66(1), 64-74. 
Ismail, I., Permanasari, A., \& Setiawan, W. (2016). Efektivitas virtual lab berbasis STEM dalam meningkatkan literasi sains siswa dengan perbedaan gender. Jurnal Inovasi Pendidikan IPA, 2(2), 190-201.

Jones, R, B. (2008). Science, technology, engineering, and math. Retrived from http://www.learning.com

Hasan, S., Bagayoko, D., \& Kelley, E. L. (1999). Misconceptions and the certainty of response index (CRI). Physics education, 34(5), 294.

Lemke, C. (2003). enGauge 21st Century Skills: Digital Literacies for a Digital Age. Neperville, IL: North Central Regional Education Lab.

Mayasari, T., Kadorahman, A., \& Rusdiana, D. (2014). Pengaruh pembelajaran terintegrasi science, technology, engineering, and mathemathics (STEM) pada hasil belajar peserta didik: Studi meta analisis, Prosiding Semnas Pensa VI "Peran Literasi Sains" (p.371377). Surabaya: UNESA.

National Research Council. (2010). Framework for science education. Washington, DC: National Academy Press.

Oligiv, C., (2000). Effectiveness of different course component in driving gains in conceptual understanding, Cambridge, Internal report, Department of Physics at MIT [on-line] URL : http://torrseal.mit.edu/effedtech/

Republika. (2015). Indonesia Perlu Masukkan Aspek STEM dalam Pendidikan. Tersedia: http://www.republika.co.id/berita/pendidikan/eduaction/15/03/08/nkvou7-indonesiaperlu-masukkanaspek-stem-dalam-pendidikan

Rustaman, N. Y., et al. (2003). Strategi Belajar Mengajar Biologi. Jurusan Pendidikan Biologi. FPMIPA. Universitas Pendidikan Indonesia

Stohlmann, M., Moore, T. J., \& Roehrig, G. H. (2012). Considerations for teaching integrated STEM education. Journal of Pre-College Engineering Education Research Journal of Pre-College Engineering Education ResearchJ-PEER) Journal of Pre-College Engineering Education Research, 2(2), 1-28. http://doi.org/10.5703/1288284314653

Sulaeman, A. ., Indrawati, \& Noeraida. (2017). Modul Pengembangan Keprofesian Berkelanjutan Mata Pelajaran Ilmu Pengetahuan Alam Kelompok Kompetensi B. Jakarta: Kemdikbud.

Sulistiyowati, S., Abdurrahman, A., \& Jalmo, T. (2018). The Effect of STEM-Based Worksheet on Students' Science Literacy. Tadris: Jurnal Keguruan Dan Ilmu Tarbiyah, 3(1), 89-96.

Suwarma, I. R., Astuti, P., \& Endah, E. N. (2015). Baloon Powered Car sebagai Media Pembelajaran IPA Berbasis STEM (Science, Thechnology, Engineering, and Mathematics). Proceed Simposium Nasional Inovasi dan Pembelajaran Sains 2015.

Utami, I. S., Septiyanto, R. F., Wibowo, F. C., \& Suryana, A. (2017). Pengembangan STEMA (Science, Technology, Engineering, Mathematic and Animation) Berbasis Kearifan Lokal dalam Pembelajaran Fisika. Jurnal Ilmiah Pendidikan Fisika Al-Biruni, 6(1), 6773. 